Issued by Sandia National Laboratories, operated for the United States Department of Energy by Sandia Corporation.

NOTICE: This report was prepared as an account of work sponsored by an agency of the United States Government. Neither the United States Government nor any agency thereof, nor any of their employees, nor any of their contractors, subcontractors, or their employees, makes any warranty, express or implied, or assumes any legal liability or responsibility for the accuracy, completeness, or usefulness of any information, apparatus, product, or process disclosed, or represents that its use would not infringe privately owned rights. Reference herein to any specific commercial product, process, or service by trade name, trademark, manufacturer, or otherwise, does not necessarily constitute or imply its endorsement, recommendation, or favoring by the United States Government, any agency thereof, or any of their contractors or subcontractors. The views and opinions expressed herein do not necessarily state or reflect those of the United States Government, any agency thereof, or any of their contractors.

Printed in the United States of America. This report has been reproduced directly from the best available copy.

Available to DOE and DOE contractors from

Office of Scientific and Technical Information

P.O. Box 62

Oak Ridge, TN 37831

Prices available from (615) 576-8401, FTS 626-8401

Available to the public from

National Technical Information Service

U.S. Department of Commerce

5285 Port Royal Rd

Springfield, VA 22161

NTIS price codes

Printed copy: A03

Microfiche copy: A01

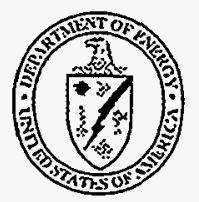




\section{DISCLAIMER}

Portions of this document may be illegible in electronic image products. Images are produced from the best available original document. 
SAND98-1737

Unlimited Release

Printed August 1998

\title{
The START III Bargaining Space
}

\author{
Thomas H. Karas \\ Arms Control Studies Department \\ Sandia National Laboratories \\ P.O. Box 5800 \\ Albuquerque, NM 87185-0425
}

\begin{abstract}
Possible START III bargaining goals and concessions should be considered in the entire context of strategic nuclear arms reductions, not in isolated compartments such as warhead dismantlement. Significant force structure and weapons complex asymmetries underlie U.S. and the R.F. (Russian Federation) negotiating interests in START III. The declining state of the Russian military and precarious Russian economic position will give the U.S. considerable bargaining advantages, but that among other asymmetries will make difficult reaching an agreement mutually perceived to be equitable. Taking the US-RF symmetries into account, this paper discusses a menu of START III measures the U.S. could ask for, and measures it could offer in return, in attempting to negotiate such an agreement.
\end{abstract}




\section{The START III Bargaining Space}

\section{Contents}

Russian Interests and Constraints___ 7

Perception of Parity ___ 8

Constrain U.S. Upload Capabilities ___ 8

Preserve Theater Nuclear Options ___ 10

Protect the ABM Treaty __ 10

Protect Dignity ___ 11

U.S. Interests and Constraints __ 12

Get START II Ratified___ 12

Make Reductions Less Reversible____ 12

Long-term Transparency of Russian Weapons Complex ___ 13

Reduce Russian Theater Nuclear Weapons ___ 14

Preserve BMD Options __ 14

Retain Reserve Warheads____ 14

Significant Asymmetries______ 15

Bargaining Chips__ 17

Measures U.S. Could Seek

Lock and Increase START II Reductions___ 17

Irreversibility ___ 17

Limit Theater Nuclear Weapons (TNW)___ 18

Long-term Transparency __ 19

Measures U.S. Could Offer _ 20

Further Reduce START III Deployment Levels ___ 20

Reduce Upload Capacity Disparities ___ 20

Financial Assistance for Dismantling Weapons ___ 21

Conclusion

Appendix 1: Projections of U.S. and Russian Strategic Nuclear Force Levels 22 


\section{The START III Bargaining Space}

\section{EXECUTIVE SUMMARY}

It is essential to consider possible START III bargaining goals and concessions in the whole context, and not in categorized compartments (e.g., warhead dismantlement, delivery system reduction, de-alerting, theater nuclear weapons). The U.S. and the R.F. (Russian Federation) have significant asymmetries in interests and constraints for START III and in the force structures and weapons complexes underlying their negotiating interests. These asymmetries are summarized in Table 1. The declining state of the Russian military and precarious Russian economic condition will give the U.S. considerable advantages at the START II bargaining table.

Taking the US-RF asymmetries into account, this paper discusses a menu of START III measures the U.S. could ask for, and measures it could offer in return, in attempting to negotiate an equitable treaty.

Measures the U.S. might seek in a START III treaty include: further reductions in deployed strategic nuclear warheads, irreversibility of reductions through warhead dismantlement; beginning to bring theater nuclear weapons under mutual control, and increased transparency into the Russian nuclear weapons complex. Russia has a strong interest in further strategic reductions. The irreversibility of those reductions will be enforced by the difficulty of retaining or replacing existing deliver systems, while any feasible warhead dismantlement monitoring would add little further assurance. Therefore, the U.S. need not expend great bargaining resources on those objectives.

The U.S. may, however, wish to apply its bargaining advantages to attempting to achieve the first steps toward two long-range goals that would enhance U.S. security:

- bringing theater nuclear weapons into the U.S.-R.F. arms control arena, and

- increasing transparency into the Russian nuclear weapons complex.

In exchange for measures relating to these objectives, the U.S. might consider offering to Russia:

- Further strategic weapons reductions approaching levels at which the Russians believe they could maintain a degree of parity with the U.S.;

- Measures to decrease the large disparities in potential deliver-system uploading capabilities that appear likely under current START IISTART III scenarios;

- Financial assistance in achieving START IISTART III reductions as rapidly as is technically possible. 
Table 1: U.S.-Russian Asymmetries Relevant to START III

\begin{tabular}{|c|c|c|}
\hline Category & U.S. & Russia \\
\hline \multicolumn{3}{|l|}{ Interest } \\
\hline Force Levels & $\begin{array}{l}\text { Lock in START II benefits at levels of adequate } \\
\text { nuclear deterrence }\end{array}$ & $\begin{array}{l}\text { Retain perceived strategic nuclear parity with U.S. at } \\
\text { affordably reduced levels }\end{array}$ \\
\hline Inteversibility & $\begin{array}{l}\text { Irreversibility of reductions by long-term } \\
\text { restraint on weapons inventories }\end{array}$ & Reduce disparity in upioad capabilities \\
\hline Transparency & $\begin{array}{l}\text { Increase U.S. understanding of RF nuclear } \\
\text { weapons and materials inventories and } \\
\text { processes while protecting U.S. secrecy } \\
\text { interests }\end{array}$ & $\begin{array}{l}\text { Maintain full control of data on nuclear weapons and } \\
\text { materials inventories and processes. }\end{array}$ \\
\hline Costs & $\begin{array}{l}\text { START II levels easily affordable; START III } \\
\text { eliminations not large }\end{array}$ & $\begin{array}{l}\text { Limit costs of large eliminations, replacements with } \\
\text { single-RV ICBMs }\end{array}$ \\
\hline TNW & $\begin{array}{l}\text { Reduce TNW as part of overall Russian nuclear } \\
\text { threat; retain limited U.S. TNW }\end{array}$ & $\begin{array}{l}\text { Preserve theater nuclear options to backstop } \\
\text { weakened conventional forces; reduce U.S. } \\
\text { nuclear SLCM }\end{array}$ \\
\hline BMD & Preserve TMD options, limited NMD options & Protect ABM Treaty \\
\hline Intangibles & Use advantages to increase security & Protect dignity: avoid appearance of U.S. dictation \\
\hline Stockpiles & $\begin{array}{l}\text { Retain reserve warheads; reduce Russian } \\
\text { inventories and production }\end{array}$ & $\begin{array}{l}\text { Limit U.S. upload potential, preserve Russian } \\
\text { warhead re-manufacturing capability }\end{array}$ \\
\hline \multicolumn{3}{|l|}{ Force Structures } \\
\hline SLBM & $\begin{array}{l}\text { SLBM reductions largely by downloading } \\
\text { (hence large upload potential); subs and } \\
\text { missiles sustainable for long term }\end{array}$ & $\begin{array}{l}\text { SLBM forces degrading rapidly; replacements slow to } \\
\text { nil; little or no potential upload capability }\end{array}$ \\
\hline SSBN & $\begin{array}{l}8 \text { or more SSBNs on patrol; SSBNs in good } \\
\text { condition }\end{array}$ & $\begin{array}{l}1 \text { or } 2 \text { SSBNs on patrol; Current SSBNs poorly } \\
\text { maintained; many nuclear subs to be dismantled }\end{array}$ \\
\hline ICBM & Service life of Minuteman III being extended & $\begin{array}{l}\text { MIRVed ICBMs degrading rapidly; production of SS- } \\
27 \text { s unable to meet START II "parity" levels }\end{array}$ \\
\hline Bomber & $\begin{array}{l}\text { Large long-range bomber/ ALCM carrier } \\
\text { upload capability }\end{array}$ & $\begin{array}{l}\text { Fewer, older long-range bombers, and those ending } \\
\text { useful service lives }\end{array}$ \\
\hline Vulnerability & $\begin{array}{l}\text { Russian counterforce threat addressed by } \\
\text { START II de-MIRVing }\end{array}$ & $\begin{array}{l}\text { Persistent U.S. theoretical short-warning counterforce } \\
\text { capabilities (including SLBM, SLCM, TNW) }\end{array}$ \\
\hline $\begin{array}{l}\text { Infrastructure } \\
\text { ICBM } \\
\text { production }\end{array}$ & $\begin{array}{l}\text { No ICBM production, but Minuteman III in } \\
\text { service-life extension }\end{array}$ & $\begin{array}{l}\text { Lost MIRVed ICBM production in Soviet breakup; } \\
\text { SS-27 in delayed production }\end{array}$ \\
\hline $\begin{array}{l}\text { SLBM } \\
\text { production }\end{array}$ & Trident D-5 SLBMs replacing C-4s & $\begin{array}{l}\text { One new SLBM in development, but with recent test } \\
\text { failures }\end{array}$ \\
\hline \multirow[t]{2}{*}{$\begin{array}{l}\text { Warhead } \\
\text { maintenance }\end{array}$} & $\begin{array}{l}\text { Nuclear warheads produced in batches by type, } \\
\text { with no continuing production; apparently } \\
\text { longer service life for warheads }\end{array}$ & $\begin{array}{l}\text { Nuclear warheads replacements regularly } \\
\text { manufactured; apparently shorter service life for } \\
\text { warheads }\end{array}$ \\
\hline & $\begin{array}{l}\text { Reconstitution of warhead production } \\
\text { capabilities would be difficult }\end{array}$ & $\begin{array}{l}\text { Existing large plant capacity for warhead production } \\
\text { (but finances for surge production doubtful). }\end{array}$ \\
\hline $\begin{array}{l}\text { NW } \\
\text { Stockpiles }\end{array}$ & $\begin{array}{l}\text { Smaller stocks of undeployed warheads and } \\
\text { fissile materials }\end{array}$ & $\begin{array}{l}\text { Very large stocks of undeployed nuclear warheads } \\
\text { and fissile materials }\end{array}$ \\
\hline Transparency & $\begin{array}{l}\text { High, but not complete, openness about nuclear } \\
\text { materials and weapons stockpiles and } \\
\text { infrastructure }\end{array}$ & $\begin{array}{l}\text { Higher secrecy about nuclear materials and weapons } \\
\text { stockpiles and infrastructure. }\end{array}$ \\
\hline
\end{tabular}




\title{
The START III Bargaining Space
}

\author{
Interviewer: Vladimir Nikolayevich, you are a consistent supporter of the ratification of the \\ START II Treaty, which many politicians and military men in Russia regard ambiguously, \\ to put it mildly. To what do you attribute your position? \\ Yakovlev: To a knowledge of the situation. \\ -From and interview with Vladimir Yakovlev, commander of Russian strategic rocket forces, pub. \\ July $2,1998$.
}

The asymmetries in interests, constraints, force structures, and weapons production complexes between the United States and the Russian Federation greatly complicate the bargaining over START III: symmetrical measures will not have symmetrical consequences. Therefore, it is essential to consider possible bargaining goals and concessions in the whole context, and not in categorized compartments (e.g., warhead dismantlement, delivery system reduction, de-alerting, theater nuclear weapons). The question could then be posed: with the overall objective of equitably increasing the net security of both the U.S. and Russia, what contributions to U.S. security do we seek from the Russians, and what contributions to their perception of their security could we offer in return?

The following four sections of this paper examine:

- Russian interests and constraints for START III

- U.S. interests and constraints

- Important asymmetries in the two sides' forces structures and weapons complexes

- START III measures the U.S. could ask for, and measures it could offer in return, in attempting to negotiate an equitable treaty.

\section{RUSSIAN INTERESTS AND CONSTRAINTS}

There is no way of knowing what will be the priorities of the Russian team that sits down to negotiate a START III treaty. However, Russian officials, parliamentarians, and unofficial analysts have discussed the strategic issues relevant to START in a variety of public fora. They have expressed views and positions both in the press and in well-reported meetings, such as the Helsinki summit and the 1997 visit of Secretary of Defense Perry to Moscow. It is possible to assemble from these many public statements and analyses a plausible picture of 
Russian strategic concerns and of the lines of agreement and disagreement about these concerns within the Russian public policy community.

\section{Perception of Parity}

From the beginning of the atomic age, Russian officials have seen nuclear weapons not merely as potential military instruments, but as symbols of strategic equivalence with the U.S. Since the collapse of Soviet power and the decline of the Russian military, Russians have talked increasingly of the role of nuclear weapons not only as ultimate guarantor of national security, but as their admission tickets to great power bargaining tables. Past the end of the cold war, they have continued to seek the appearance of nuclear parity with the U.S.

Although START II allows for numerical parity in deployed strategic nuclear weapons, it finds Russia unable to sustain that parity for long. As the permitted delivery systems age, Russia seems unlikely to be able to afford to maintain many more than 1,500 deployed strategic nuclear weapons into the 2007-2010 period.' The U.S. has offered to begin negotiations on ceilings of 2,000 to 2,500 weapons immediately upon Russian ratification of the START II treaty.

The least difficult way for Russia to maintain strategic nuclear parity with the U.S. into the first two decades of the twenty-first century will be to negotiate a START III treaty that brings U.S. deployed weapons down to the levels that Russia can afford to sustain. This fact should give the U.S. considerable bargaining leverage in the negotiations. On the other hand, many Russians see START II as an unfair bargain imposed by the U.S. from a position of strength. At least some Russians seem prepared to abandon START II, even if that means accepting an apparent strategic inferiority in the near term. Some of the latter argue that Russia should keep its 10-MIRV SS-18s as long as possible, in the meantime developing a comparable replacement for Russian manufacture. Russian START II proponents argue that such a new missile is economically unrealistic.

Although the Russians are interested in the perception of strategic nuclear parity with the U.S., they would probably like to keep the mutual levels higher than those of the second tier of nuclear powers: China, France, and the United Kingdom.

\section{Constrain U.S. Upload Capabilities}

Russian critics of START II have pointed out that under the treaty Russia must dismantle (at great expense) many delivery vehicles, while the U.S. will be able to meet warhead ceilings by merely downloading missiles. The downloaded warhead slots (combined with substantial bomber reconversion capacity) will give the U.S. a substantial advantage in upload capability. If START III permits further reductions by means of downloading, the upload gap will still widen (see Figure 1).

\footnotetext{
'The data table for Figure 1 summarizes the estimates made here for future Russian strategic nuclear forces. These estimates are broken down into more detail in the charts and tables of Appendix 1. The introduction to Appendix 1 describes the considerations that underlie these assumptions.
} 


\section{Strategic Nuclear Warhead Scenarios}

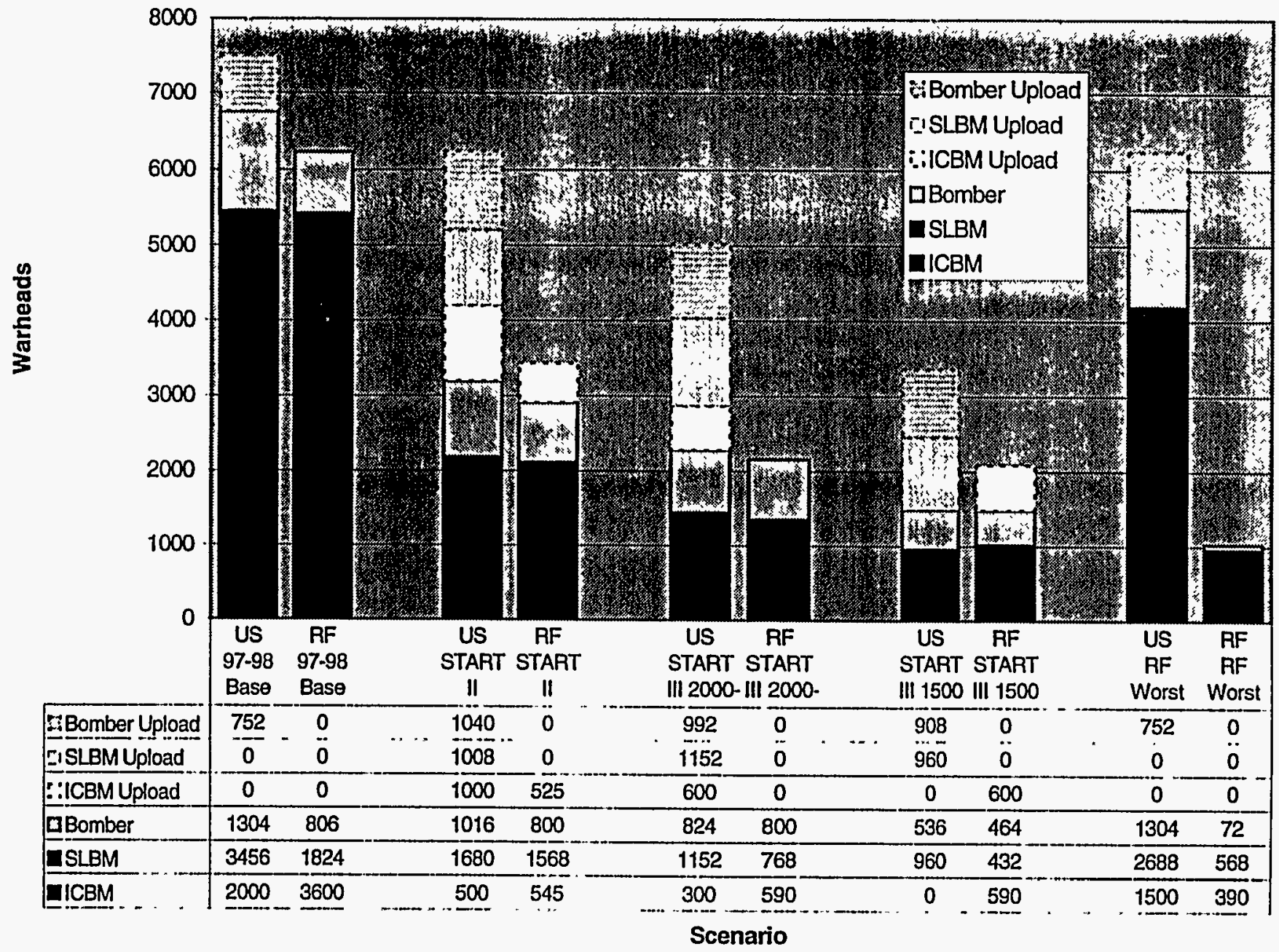

(Estimates and assumptions underlying Figure 1can be found in Appendix 1)

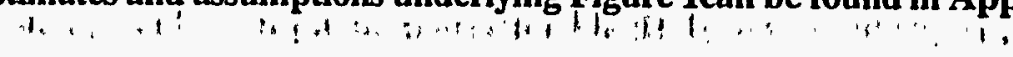


Given the many Russian expressions of concern about the disparity in upload capabilities, it may be that the Russians would like to see START III measures that would limit that disparity. If so, the U.S. would have additional bargaining leverage on other issues.

One means for Russia to assure itself that U.S. upload capabilities have been limited would be to observe the dismantlement of the removed warheads and many of their reserve counterparts. Given the very low level of current U.S. production capacity and the difficulty the U.S. would have in concealing undeclared spare warheads, Russia could be fairly certain that warheads would not be available for upload. However, monitored dismantlement would involve costly and intrusive inspection systems that are unlikely to be acceptable to Russia, let alone to the U.S. Therefore, more promising measures to prevent rapid uploads will probably relate to delivery systems rather than warheads. Some concepts are discussed further below.

\section{Limit Costs}

In an effort to reduce the cost burdens to Russia of carrying out START II eliminations rapidly, the U.S. executive branch has agreed to an amendment to START II that would allow the Russians to "deactivate" until elimination by 2007 the systems originally scheduled for elimination by 2003 . The U.S. is also helping Russia build storage facilities for components of dismantled nuclear weapons.

Russia would find it very costly to maintaining strategic force levels that would not be at all difficult for the U.S. to maintain. Dismantling obsolete systems at the slowest possible pace will also be costly, but perhaps not as costly as dismantling them at mandatory, scheduled rates under treaty-required inspections. Under START III, the Russians will be trying to keep these costs to themselves as limited as possible.

\section{Preserve Theater Nuclear Options}

Russians have apparently resisted bringing theater nuclear weapons (TNW) into START discussions. At Helsinki, the two presidents agreed that measures relating to TNW (or "nonstrategic") nuclear weapons and nuclear SLCMs would be subjects for discussion as separate issues in the START III context. Some Russian analysts see U.S. nuclear SLCMs as potential strategic threats to Russia. On the other hand, Russian officials have stated an intention to rely on theater nuclear weapons to backstop their severely weakened conventional forces. One potential threat could come from China in the Far East. NATO forces are likely for some time to have conventional superiority over Russian forces. In addition, some Russians have expressed concerns that an expanded NATO could, despite declared "plans," ultimately base theater nuclear weapons or counterforce-capability precision-guided conventional weapons along Russian borders. This possibility, they imply, strengthens the need for Russian theater nuclear weapons.

\section{Protect the ABM Treaty}

Whatever one thinks the Russians ought to think about ballistic missile defense (BMD) now that the cold war is over, the fact is that across the board in Russia there is little tolerance 
for revisions of the ABM Treaty that would allow-or lay the basis for-sizeable national $\mathrm{BMD}$. Instead, Russians see BMD as weakening an already diluted Russian strategic nuclear deterrent. Russian views are very likely colored by the fact that Russia today is economically incapable of sustaining its current strategic nuclear forces, let alone developing and constructing a national BMD system. Deploying offensive countermeasures to BMD would also be costly. (The new SS-27 does have excess payload capability for this purpose.)

If the Russians became convinced that the U.S. was going to withdraw from the ABM Treaty, they would be faced with a difficult choice. They could either a) reject START II and START III and accept many years of strategic nuclear inferiority, but at least preserve options for countering U.S. missile defenses, or b) achieve numerical parity in the near term but risk that in the longer term that U.S. BMD will render their "equal" forces permanently inferior.

Another Russian concern with BMD is that substantial U.S. BMD deployments could encourage China to expand its own missile forces in a compensatory effort to maintain a nuclear deterrent against the U.S. That expansion, in turn, would also increase Chinese nuclear capability against Russia. ${ }^{2}$

\section{Protect Dignity}

Many Russians see START II as something of a humiliation imposed by the strong and crafty U.S. on weakened and confused Russians. The Russian parliament has already demonstrated its willingness to act in a way that appears to undermine objective Russian interests by delaying for so long the ratification of START II. This delay did have the benefit to Russia of obtaining a U.S. commitment to proceed quickly with a START III Treaty that could correct some of the perceived inequities of START II. However, the delay also seems to have been motivated by a sense among Russian parliamentarians that with START II, and then with NATO expansion, the U.S. was attempting to push Russia around. Should the U.S. attempt to push its START III bargaining advantages too far, the parliament might feel that it could live more comfortably with strategic weaknesses imposed by Russian economic straits than with those dictated by the U.S.

\footnotetext{
${ }^{2}$ See for example the comments of two Russian hard-liners:

The only reliable guarantee of military balance at present is our overwhelming superiority in the strategic sphere. However, if Russia sharply reduces its strategic nuclear forces, and China, on the contrary - frightened by American plans to deploy a strategic antimissile defense system-embarks upon a serious build-up of its nuclear potential, our superiority will disappear. This in turn, if the current partner relations between Moscow and Beijing evolve over time in the direction of confrontation, will directly stimulate the Chinese to effect military expansion in the Far East and Siberia.

Aleksey Podberezkin and Anton Surikov: "Illusions of Peace: Russia's Military Policy Requires a Selection of Priorities" Zavtra No 38, September 1997, p. 6 (SOV-97-276).
} 


\section{U.S. INTERESTS AND CONSTRAINTS}

\section{Get START II Ratified}

The major accomplishment of START II was to get Russian agreement to abolish MIRVed ICBMs, particularly the SS-18s. The destabilizing characteristics of fixed, MIRVed ICBMs have been well discussed elsewhere and should not need repeating here. With START II, however, if the Russians were to retain approximate numerical parity with the U.S in deployed strategic nuclear weapons at the 3,000-3,500 deployed, they would have to build something like 600 new single-RV ICBMs. To alleviate this burden, the U.S. has promised that upon START II ratification it will begin immediately to negotiate on START III at 2,0002,500 .

The question arises: if the Russians will be hard-pressed to maintain even 1,500 weapons, why negotiate with them? In the absence of a START II commitment, the Russians are likely to cling to their MIRVed, silo-based ICBMs for as long as possible. Thus, during a period of economic and political uncertainty, combined with a dubious early-warning system, the Russians would keep on alert 2,000-3,000 of their most destabilizing missiles.

In addition, they may to try to develop an SS-18 or SS-24 follow-on as a means of trying to regain numerical parity with U.S. strategic nuclear forces. In the near term, they may not succeed. It does seem unlikely that, by 2010, Russia could retain its current MIRVed ICBMs or deploy new ones even if it wanted to. However, to abandon START II now implies a faith that the Russian economy will never recover and that Russia will be never be able to regain strategic parity with the U.S.

A U.S. decision to take advantage of current Russian weakness to achieve numerical superiority over Russian strategic nuclear forces would not only stimulate a Russian effort to catch up in the long term, it would also play into the hands of those in Russia who already argue that the U.S. is exploiting its "sole superpower" role to dictate terms to Russian foreign policy -as, for example, with the expansion of NATO. Although the shadow of its Soviet self, Russia can still make considerable trouble for U.S. foreign policy, particularly in the Middle East. U.S. strategic nuclear "superiority" is not likely to be a usable tool for countering the kinds of international political difficulties that Russia can still make for the U.S. Moreover, the chances of a Russian teaming with China to oppose U.S. "hegemonism" would probably grow as well.

Proceeding with the START I/START III combination, then, would have the dual benefits of reinforcing the post-cold war strategic nuclear rapprochement between the U.S. and Russia and of locking in a Russian commitment to stay at the reduced arms levels that economics is going to force on them in the near term.

\section{Make Reductions Less Reversible}

At their Helsinki summit, Presidents Clinton and Yeltsin agreed that START III should include: 


\begin{abstract}
Measures relating to the transparency of strategic nuclear warheads and inventories and the destruction of strategic nuclear warheads and any other jointly agreed technical and organizational measures, to promote the irreversibility of deep reductions including prevention of a rapid increase in the number of warheads. ${ }^{3}$
\end{abstract}

In this sentence, the "measures" are clearly directed to the end of promoting "...the irreversibility of deep reductions including prevention of a rapid increase in the number of warheads." Recent government studies have focussed on one element of one of the means that might contribute to the end: measures relating to the transparency of the destruction of strategic nuclear warheads. Yet, without an extremely high —and almost certainly unobtainable in the near term-degree of transparency into, and reduction of, nuclear warhead inventories and production, transparency of strategic warhead destruction will do nothing to assure the U.S. that Russia would not have warheads available for a rapid increase in deployments.

What can give the U.S. high confidence in the irreversibility of deep reductions is the impending lack of long-range means for delivering weapons to the U.S. Thus, the U.S. would do well to focus on the "other jointly agreed technical and organizational measures" to promote irreversibility.

\title{
Long-term Transparency of Russian Weapons Complex
}

In addition to calling for measures in START II relating to transparency of nuclear warhead inventories and destruction, the Helsinki agreement calls for the two sides "to consider the issues related to a previously agreed objective, transparency of nuclear materials." The U.S. does have important interests in increased transparency into Russian nuclear materials:

- More reliable estimates of current weapons inventories and production capabilities, enabling greater predictability of future weapon deployments should the Russians build new delivery systems;

- Better verification of possible future, very deep reductions that include both strategic and tactical weapons;

- More confidence that Russia is preventing theft or loss of loose nuclear weapons materials;

- Closer cooperation in long-term disposal of surplus fissile materials;

- Steps toward eventual global system of nuclear materials accounting and surveillance.

Although objectively Russia ought to share these interests, in fact it is doubtful that Russians today will place much priority on them. Therefore, to obtain greater nuclear transparency, the U.S. may need to offer to meet other, more pressing, Russian needs in exchange.

\footnotetext{
${ }^{3}$ White House Fact Sheet, "Joint Statement on Parameters of Future Reductions in Nuclear Forces," March $21,1997$.
} 


\section{Reduce Russian Theater Nuclear Weapons}

The Helsinki agreements also refer to having "experts explore, as separate issues [in the START III context], possible measures relating to nuclear long-range sea-launched cruise missiles and tactical nuclear systems, to include appropriate confidence-building and transparency measures." For its part, the U.S. would like to see some steps toward bringing Russian tactical nuclear weapons under control because:

- Current numbers of Russian deployed and non-deployed tactical nuclear weapons remain a large unknown to the U.S.;

- As numbers of permitted strategic warheads go down, the numbers of tactical warheads - in principle capable of strategic use-become increasingly important.

The Russians have long been interested in controlling U.S. nuclear SLCMs, but the two sides abandoned formally limiting them under START I in favor of politically binding declarations about future deployments. ${ }^{4}$ Russia might also like to see the remaining U.S. nuclear bombs removed from Europe, but is unlikely to be willing to trade much of its own theater nuclear capability in exchange.

\section{Preserve BMD Options}

The Clinton Administration has reaffirmed a commitment to the ABM Treaty while proceeding with theater BMD programs. The Congressional majority urges deploying a national BMD system, after amending the ABM Treaty with Russian agreement if possible, but by withdrawing from the Treaty unilaterally if necessary. The Administration is satisfied with current U.S.-Russian agreements about what may be tested within ABM Treaty confines. But it remains unclear if the Senate will support those agreements or ratify the "Successor States" MOU of September 1997 that redefines the parties to the treaty to account for the breakup of the Soviet Union.

Preservation of the ABM Treaty will certainly be a condition of Duma ratification of START II and START III. The Senate's resolution of ratification of START II stated that ratification did not imply commitment either to changing ABM Treaty membership or to staying in the Treaty. It is clear that U.S. negotiators will have to preserve at least as much theater missile defense latitude as the Russians have thus far agreed to, but it is not clear that this will be enough for the Senate.

\section{Retain Reserve Warheads}

Because the U.S. now lacks a large-scale warhead manufacturing infrastructure, it will have an interest in START III in preserving some downloaded warheads for inspection by disassembly and for replacement of defective deployed warheads. Some in the military and DOE believe that entire alternate classes of downloaded warheads should be retained, where

\footnotetext{
${ }^{4}$ The problem of designing a reliable verification régime for nuclear SLCM limitations seemed insoluble, and perhaps still does. See U.S. Congress, Office of Technology Assessment, Monitoring Limits on Sea-Launched Cruise Missiles (Washington, D.C:GPO, September 1992), OTA-ISC-513.
} 
feasible, as a hedge against the possibility that a deployed type suffers an unforeseen commonmode failure that requires complete replacement.

These reserve warheads could, in principle, be used for uploading START-reduced delivery systems rather than for mere replacement. This puts the Helsinki objective of increasing irreversibility by means of warhead destruction and inventory transparency ${ }^{5}$ at odds with the U.S. security objective of retaining replacement spares.

\section{SIGNIFICANT ASYMMETRIES}

The U.S. and Russia will go to the START III bargaining table with significant asymmetries not only in immediate strategic interests, but also in economic, political, force structure, and infrastructure factors that set the treaty negotiation context. These differences complicate the prospective negotiations, but may also offer combinations of compromise and goal attainment that are on the whole different yet still equitable for the two sides. Table 2 summarizes the relevant asymmetries.

Historically, U.S. and Soviet negotiators have constructed agreements each of whose provisions applied equally to both sides, even though structural asymmetries meant those provisions did not affect both sides equally. This allowed them a simple way of demonstrating to domestic constituencies the fairness of the agreements. In the end, each side needed to judge whether, on balance, the entire package of provisions resulted in an agreement that was equitable overall. As Table 2 shows, U.S.-Russian strategic nuclear asymmetries are large and growing. Many Russians see the START II Treaty as inequitable, and the U.S. has offered to ameliorate the perceived inequities in START III. At the same time, the U.S. will not (and Russia should not expect that it will) enter into these negotiations merely to restore a Russian sense of fairness. Thanks to several of the asymmetries that are in the U.S.' favor, the U.S. has an opportunity to ask for concessions by the Russians that could enhance U.S. security in the longer term in exchange for U.S. concessions that help solve some nearterm Russian problems.

\footnotetext{
${ }^{5}$ See above, p. 12.
} 


\begin{tabular}{|c|c|c|}
\hline Category & U.S. & Russia \\
\hline \multicolumn{3}{|l|}{ Interest } \\
\hline Force Levels & $\begin{array}{l}\text { Lock in START II benefits at leveis of adequate } \\
\text { nuclear deterrence }\end{array}$ & $\begin{array}{l}\text { Retain perceived strategic nuclear parity with U.S. at } \\
\text { affordably reduced levels }\end{array}$ \\
\hline Irreversibility & $\begin{array}{l}\text { Irreversibility of reductions by long-term } \\
\text { restraint on weapons inventories }\end{array}$ & Reduce disparity in upload capabilities \\
\hline Transparency & $\begin{array}{l}\text { Increase U.S. understanding of RF nuclear } \\
\text { weapons and materials inventories and } \\
\text { processes while protecting U.S. secrecy } \\
\text { interests }\end{array}$ & $\begin{array}{l}\text { Maintain full control of data on nuclear weapons and } \\
\text { materials inventories and processes. }\end{array}$ \\
\hline Costs & $\begin{array}{l}\text { START II levels easily affordable; START III } \\
\text { eliminations not large }\end{array}$ & $\begin{array}{l}\text { Limit costs of large eliminations, replacements with } \\
\text { single-RV ICBMs }\end{array}$ \\
\hline TNW & $\begin{array}{l}\text { Reduce TNW as part of overall Russian nuclear } \\
\text { threat; retain limited U.S. TNW }\end{array}$ & $\begin{array}{l}\text { Preserve theater nuclear options to backstop } \\
\text { weakened conventional forces; reduce U.S. } \\
\text { nuclear SLCM }\end{array}$ \\
\hline BMD & Preserve TMD options, limited NMD options & Protect ABM Treaty \\
\hline Intangibles & Use advantages to increase security & Protect dignity: avoid appearance of U.S. dictation \\
\hline Stockpiles & $\begin{array}{l}\text { Retain reserve warheads; reduce Russian } \\
\text { inventories and production }\end{array}$ & $\begin{array}{l}\text { Limit U.S. upload potential, preserve Russian } \\
\text { warhead re-manufacturing capability }\end{array}$ \\
\hline \multicolumn{3}{|l|}{ Force Structures } \\
\hline SLBM & $\begin{array}{l}\text { SLBM reductions largely by downloading } \\
\text { (hence large upload potential); subs and } \\
\text { missiles sustainable for long term }\end{array}$ & $\begin{array}{l}\text { SLBM forces degrading rapidly; replacements slow to } \\
\text { nil; little or no potential upload capability }\end{array}$ \\
\hline SSBN & $\begin{array}{l}8 \text { or more SSBNs on patrol; SSBNs in good } \\
\text { condition }\end{array}$ & $\begin{array}{l}1 \text { or } 2 \text { SSBNs on patrol; Current SSBNs poorly } \\
\text { maintained; many nuclear subs to be dismantled }\end{array}$ \\
\hline ICBM & Service life of Minuteman III being extended & $\begin{array}{l}\text { MIRVed ICBMs degrading rapidly; production of SS- } \\
27 \text { s unable to meet START II "parity" levels }\end{array}$ \\
\hline Bomber & $\begin{array}{l}\text { Large long-range bomber/ ALCM carrier } \\
\text { upload capability }\end{array}$ & $\begin{array}{l}\text { Fewer, older long-range bombers, and those ending } \\
\text { useful service lives }\end{array}$ \\
\hline Vulnerability & $\begin{array}{l}\text { Russian counterforce threat addressed by } \\
\text { START II de-MIRVing }\end{array}$ & $\begin{array}{l}\text { Persistent U.S. theoretical short-warning counterforce } \\
\text { capabilities (including SLBM, SLCM, TNW) }\end{array}$ \\
\hline $\begin{array}{l}\text { Infrastructure } \\
\text { ICBM } \\
\text { production }\end{array}$ & $\begin{array}{l}\text { No ICBM production, but Minuteman III in } \\
\text { service-life extension }\end{array}$ & $\begin{array}{l}\text { Lost MIRVed ICBM production in Soviet breakup; } \\
\text { SS-27 in delayed production }\end{array}$ \\
\hline $\begin{array}{l}\text { SLBM } \\
\text { production }\end{array}$ & Trident D-5 SLBMs replacing C-4s & $\begin{array}{l}\text { One new SLBM in development, but with recent test } \\
\text { failures }\end{array}$ \\
\hline \multirow[t]{2}{*}{$\begin{array}{l}\text { Warhead } \\
\text { maintenance }\end{array}$} & $\begin{array}{l}\text { Nuclear warheads produced in batches by type, } \\
\text { with no continuing production; apparently } \\
\text { longer service life for warheads }\end{array}$ & $\begin{array}{l}\text { Nuclear warheads replacements regularly } \\
\text { manufactured; apparently shorter service life for } \\
\text { warheads }\end{array}$ \\
\hline & $\begin{array}{l}\text { Reconstitution of warhead production } \\
\text { capabilities would be difficult }\end{array}$ & $\begin{array}{l}\text { Existing large plant capacity for warhead production } \\
\text { (but finances for surge production doubtful). }\end{array}$ \\
\hline $\begin{array}{l}\text { NW } \\
\text { Stockpiles }\end{array}$ & $\begin{array}{l}\text { Smailer stocks of undeployed warheads and } \\
\text { fissile materials }\end{array}$ & $\begin{array}{l}\text { Very large stocks of undeployed nuclear warheads } \\
\text { and fissile materials }\end{array}$ \\
\hline Transparency & $\begin{array}{l}\text { High, but not complete, openness about nuclear } \\
\text { materials and weapons stockpiles and } \\
\text { infrastructure }\end{array}$ & $\begin{array}{l}\text { Higher secrecy about nuclear materials and weapons } \\
\text { stockpiles and infrastructure. }\end{array}$ \\
\hline
\end{tabular}




\section{BARGAINING CHIPS}

This section offers examples of measures the U.S. could ask for that could help it achieve its larger goals for START III. It then goes on to give examples of measures the U.S. could offer that might help satisfy Russian interests.

\section{Measures U.S. Could Seek}

\section{Lock and Increase START /I Reductions}

START II ratification would not be a START III treaty measure per se, but the U.S. has already conditioned START III reductions on Russian START II ratification. The prospects of Duma ratification have ebbed and flowed in 1997 and 1998. If the Duma fails to ratify, but indicates an interest in a treaty at START III levels as an alternative, the U.S. might face the difficult choice of backing down from a near-ultimatum or forgoing a new agreement that could result in the same (de-MIRVing) benefits of START II.

\section{Irreversibility}

The conditions and prospects of Russian delivery systems almost guarantee a high degree of irreversibility to Russian START reductions, at least until they can reconstitute the means to produce, field, and deploy replacement systems. The eliminated systems will not be worth trying to restore, while major new production would be very difficult to afford. Some in the U.S see warhead destruction as an irreversibility measure. However, the Russian stockpile and infrastructure are large, and the uncertainties great. The destruction only of warheads (or numbers of warheads) removed from START-reduced systems- even if it could be reliably verified—would provide no guarantee that the Russians did not have alternatives available or that they could not quickly manufacture replacements. To achieve verifiable stockpile and production limitations would require massive changes in Russian practices, would be very costly, and could easily lead to "equal" measures that weighed very unequally on the U.S. side because of the asymmetries in the two weapons complexes.

Even without actual warhead eliminations, the U.S. will be protected from "a rapid increase in the number of warheads" by the fact that the Russians will have few strategic systems with which to deliver them. On the other hand, if Russia did find the means to produce many new delivery systems, they could probably draw on existing weapons or production capabilities beyond the stock of START-removed warheads. ${ }^{7}$ Thus elimination of

\footnotetext{
${ }^{6}$ See Helsinki summit quotation cited at footnote 3.

${ }^{7}$ On the one hand, if this is a genuine possibility, it increases the risk to the U.S. of a Russian breakout from the prospective treaty: if they could build new delivery systems, the Russians should not find it difficult to supply them with warheads. On the other hand, to the degree that the U.S. retains some "upload" advantages, it will have a hedge against this possibility. In addition, it seems unlikely that the Russians could develop and produce large numbers of a new delivery system so secretly that the U.S. would not be able to respond appropriately.
} 
that stock of warheads would not add much, if anything, to U.S. confidence in the difficulty of a Russian breakout from the Treaty.

In sum, "reversibility" is a far larger problem for Russia than for the U.S.; the U.S. need not spend many of its bargaining chips to attain that goal, but reasonably could instead concentrate on determining what irreversibility measures it might offer the Russians in exchange for other Russian concessions.

\section{Limit Theater Nuclear Weapons (TNW)}

As noted above, at Helsinki, the two presidents agreed that measures relating to TNW (or "non-strategic") nuclear weapons and nuclear SLCMs would be subjects for discussion as separate issues in the START III context. They have not, however, specified how many and what types of TNW they believe they need. What the Russians have not done is specify how many theater nuclear weapons, deployed on what kinds of delivery systems, that they think they need to keep. ${ }^{8}$ (The U.S. has specified that it maintains some nuclear bombs in Western Europe and some TLAM-N nuclear SLCMs in U.S. storage). Although the Russians resisted inclusion of "non-strategic" systems in START III, the U.S. might explore whether there would be some give on this issue in exchange for some of the kinds of concessions discussed below.

At a minimum, the two sides might consider something like the "politically binding" unilateral declarations on nuclear SLCMs that the two sides made parallel with the START I Treaty. The two sides would declare annually how many of what types of TNW they were deploying and what maximum numbers they might deploy in the future.

A more ambitious objective would be to obtain an agreed ceiling on TNW. One proposal for doing this would turn some of the warhead stockpile asymmetries between the two sides into an advantage. The agreed measure would be a ceiling on all assembled warheads. Included in this ceiling on the U.S. side would be its smaller number of deployed theater warheads and its larger number of reserve strategic warheads. Russia's TNW would apply toward the ceiling, while its larger weapons production capacity would allow it to maintain a much smaller reserve of strategic weapons. ${ }^{9}$

\footnotetext{
${ }^{8}$ The Natural Resources Defense Council estimated that at the end of 1997, Russia may have had about 4000 non-strategic nuclear warheads deployed (including about 1200 on ABM and SAM systems). See William M. Arkin, Robert S. Norris, and Joshua Handler, Taking Stock: Worldwide Nuclear Deployments 1998 (Washington, DC: Natural Resources Defense Council, March 1998, p. 27. How many tactical delivery systems are actually operational, with crews trained for nuclear delivery, is questionable, particularly considering the deteriorating condition of Russian military forces overall. The NRDC report also estimates that Russia might have as many as 12,000 additional non-strategic warheads in storage, either scheduled for elimination or held in reserve.

${ }^{9}$ If the U.S. decided how many total Russian warheads it could live with, and Russia decided how many total U.S. warheads it could live with, the two totals need not be identical. The two sides could agree on a common ceiling (this keeping the treaty requirements "equal"), then each could retain the number within that ceiling that it felt it needed.
} 


\section{Long-term Transparency}

The U.S. is likely to achieve confidence in its understanding of Russian nuclear weapons stockpiles and infrastructure only after some years of close correspondence between information that Russians supply about these things, the actions they take, and our unilaterally acquired information. The more information the Russians supply, the more difficult for them it would be in the long run to offer and maintain a coherent false picture of their activities. Verification offers confidence in the short-term irreversibility of specific actions.

Transparency offers confidence in the long term that a broader range of possibly dangerous actions will be more difficult to conceal, and lays the basis for more effective verification measures in the future.

The United States has already revealed substantial amounts of information about its nuclear materials stockpiles and its weapons production complex. ${ }^{10} \mathrm{~A}$ good starting place with Russia would be to get at least that much information. Ideally transparency measures would begin with declarations by both sides of the following:

- Production of highly enriched uranium (HEU): places, times, amounts

- HEU stockpiles: places, amounts

- Plutonium $(\mathrm{Pu})$ production: places, times, amounts

- Pu reprocessing: places, times, amounts

- Amounts of HEU and Pu in weapons

- Pu stockpiles (amounts, places)

- Removals from stockpiles, accounting losses of HEU and Pu

- Component fabrication, recycling, dismantlement: places, numbers, masses

- Components stored (pre-assembly, post-dismantlement)

- Weapons: inactive, reserve, active/deployed (types, numbers, places)

- Weapons production facilities: locations, capacity, current rates of dismantlement and production

- Projected requirements for warhead replacement at START III deployment levels.

Meeting requests for visits to various sites on the provided lists could provide some confidence in the veracity of these declarations. These would not be inspections in the strict

\footnotetext{
${ }^{10}$ See Plutonium: The First Fifty Years; United States Plutonium Production Acquisition, and Utilization From 1944 Through 1994 (U.S. DOE, February 1996, DOE/DP-0137) and Linking Legacies: Connecting the Cold War Nuclear Weapons Production Processes To Their Environmental Consequences (U.S. DOE, January 1997, DOE/DP-0319).
} 
sense of the word, and the "visitors" would have to make post-visit evaluation of the accuracy and completeness of the information they were able to gather. Over the long run, the declarations would be examined for consistency with each other, with later declarations, with other public data, with unilaterally collected information, and with observed actions.

\section{Measures U.S. Could Offer}

Should U.S. policymakers decide that some or all of the above measures are worth seeking, then they will also need to consider what incentives might be offered to win Russian assent. The following options, taking into account the asymmetries discussed above in this paper, suggest things the U.S. might concede in exchange for things it might want.

\section{Further Reduce START III Deployment Levels}

To alleviate Russian force structure difficulties, the U.S. could agree to reduce START III warhead ceilings from the 2,000-2,500 level of Helsinki to something like 1,500. Going to this level may require some revisions in U.S. strategic nuclear targeting policy, and would have to be considered in that light.

\section{Reduce Upload Capacity Disparities}

It is difficult to imagine a START III that would completely eliminate the disparities in upload capability between U.S. and Russian strategic forces (and, given the force and warhead inventory asymmetries, it might not even be prudent to do so.) However, there are several measures the U.S. could consider to narrow the gap.

\section{Replace Reentry Vehicle Platforms}

A means of reducing the U.S. ballistic missile upload capability would be to replace the RV platforms on missiles that are downloaded to meet START III warhead ceilings. The 3MIRV Minuteman III bus and the 8-MIRV Trident D-5 busses could be destroyed and replaced with single-RV platforms. Developing and producing the new platforms, while not technically difficult, would be expensive. It would, however, retain somewhat greater attackplanning flexibility than the next measure below. First, since each missile would have only 4 or 5 warheads, fewer warheads need be expended to reach isolated targets. Second, the excess throw-weight then available on each missile should give the missiles greater range than they had when fully loaded.

\section{De-Tube SSBNS}

To download fewer RVs from each SLBM (and thus reduce the upload potential), the U.S. could remove or render permanently inoperable several launch tubes from each SSBN. Such conversions seem likely to be less costly than producing new RV platforms. From the Russian point of view, the slightly reduced operational flexibility should be further compensation for the still large U.S. upload capabilities residing in ICBMs and bombers. 
A much cheaper alternative would be simply to reduce the number of SSBNs, but this would come at the cost of being able to keep fewer submarines at sea and thus increasing theoretical SSBN vulnerability.

\section{Financial Assistance for Dismantling Weapons}

Russia faces enormous expenses for both treaty-related and non-treaty-related weapons dismantling: chemical weapon stockpiles, nuclear submarines (strategic and non-strategic), liquid-fueled missiles, and nuclear warheads. The U.S. could offer financial assistance for START-related eliminations. Not only would this provide some incentive for proceeding with START on U.S. terms, but it would also remove some of the (largely valid) argument that the burdens of START reductions fall unevenly on the Russian side.

Whether such a measure can overcome congressional resistance is another question. Financial assistance to Russia for dismantling weapons will continue to be controversial in the U.S. In particular, critics will question why one or another Russian military expenditure could not have gone to dismantlement instead, and therefore whether the U.S. was not financing Russian military capabilities.

\section{CONCLUSION}

Although the many asymmetries between U.S. and Russian strategic forces and nuclear weapons infrastructures make arriving at an equitable START III Treaty difficult, on the whole they constitute a bargaining space in which balanced trades are possible. The U.S. has considerable advantages in this bargaining space which might be exploited to arrive at an agreement that would enhance long-term U.S. security while avoiding the appearance of dictating terms to Russia. 


\section{APPENDIX 1: PROJeCtions OF U.S. AND RUSSIAN StRATEGIC NuCLEAR FORCE LEVELS}

The following series of tables expands on the numerical estimates of Figure 1. The baseline numbers draw heavily on Nuclear Resources Defense Council figures published by the Bulletin of the Atomic Scientists. Projections rest on some of the following major assumptions:

- Russian SS-19 and SS-18 missiles are ending their service lives and no service-life extension programs will likely be feasible (SS-18 and 24 production facilities were lost to Ukraine with the breakup of the Soviet Union).

- The decline of the Russian SSBN force will continue; new Borey class (also known as the Yuri Dolgorukiy 955-class) SSBNs will be available in limited numbers (1 or 2) if at all.

- Production of SS-27 (Topol-M) ICBMs at rates much greater than 30 year in the first decade of the $21^{\text {st }}$ century is unlikely; $10-15$ per year is more likely.

- A new long-range strategic bomber to replace the aging, already depleted, Russian bomber force will not be available; the number of deployed strategic bombers will continue to decline.

- U.S. former strategic bombers that have been converted to conventional roles could be converted back to nuclear delivery configurations.

Across the spectrum of published Russian commentary on strategic forces, analysts concur with the assumptions above about Russian capabilities. The major disagreement between START II opponents and proponents is whether Russia could afford to extend the service lives of a portion of its MIRVed ICBMs until 2010, build a new factory for MIRVed ICBMs, and then turn them out at rates that would match U.S. deployed warhead numbers at START I levels. A recent pair of opposed articles summarizes the situation as seen by antiand pro-START II ratification Duma deputies:

Aleksey Ivanovich Podberezkin (Deputy Chairman of RF State Duma International Affairs Committee) and Anton Viktorovich Surikov, (Director of Information-Analysis Center of Institute of Defense Research), "Opinion 1": "A Treaty Giving the United States Advantages: START II Ratification Should Be Revisited After 2000," and Aleksey Georgiyevich Arbatov (Deputy Chairman of State Duma Defense Committee, Doctor of Historical Sciences) and Colonel (Reserve) Petr Borisovich Romashkin (consultant to Yabloko group in the RF State Duma), rubric "Opinion 2": "There Is No Alternative to START II Ratification: Since Russia Extremely Needs the Next Treaty, START III," both articles in Nezavisimoye Voyennoye Obozreniye, 20-26 February 1998, No. 7, p 6 (FBIS-SOV-98-89). 
The chart and supporting tables that follow project four scenarios from an estimate of current U.S. and Russian strategic nuclear force compositions. The START II scenario indicates plausible forces for a ceiling of 3,000-3,500 deployed warheads-a ceiling that by most accounts Russia would have a very difficult time maintaining as its MIRVed ICBMs were removed from service. Two START III scenarios are presented: one with the now-planned ceiling of 2,000-2,500 warheads and one with a ceiling of 1500 . The latter level is perhaps a more plausible one for the Russian side, since its ability to maintain larger numbers of SLBMs and bomber-deployed weapons is questionable. In the scenario labeled "RF Worst Case," the U.S. maintains forces at the START I level (as required by law until Russia ratifies START II) while Russia cannot find the means to keep more than about 1,000 strategic warheads deployed.

Some Russian analysts would say that even this projection is optimistic. For example, Yuriy Maslyukov, chairman of the Russian State Duma Economic Policy Committee:

Russian strategic nuclear forces and supporting systems have degraded to such an extent over the last six years because of chronic underfunding that their total disappearance by 2005-2007 is a realistic prospect. With regard to the land component of the strategic nuclear forces --the Strategic Missile Troops, which at present remain battleworthy - the mass withdrawal from service of missile complexes established in Soviet times is expected in 2001-2006. Within the framework of rearmament of the Strategic Missile Troops, the Defense Ministry leadership is planning to bring into service 30-40 Topol-M missile complexes each year during 2000-2010.

This is the most optimistic scenario; yet, if it is implemented, it will provide a Strategic Missile Troops grouping with a numerical strength three - four times smaller than the START II and prospective START III treaties permit. At the same time another scenario is more likely. Given the forecast budget difficulties, the level of funding of the Strategic Missile Troops will remain very low, which will make it possible to bring into service no more than 10 Topol-M missile complexes each year. This means that by 2010 approximately 100 Topol-M complexes would be in service - an order of magnitude fewer than the START II and START III treaties permit.

With regard to the naval and aviation component of the strategic nuclear forces - naval strategic nuclear forces and aviation strategic nuclear forces - the processes of degradation are now irreversible. In the admission of Defense Ministry and Security Council representatives, aviation strategic nuclear forces will cease to exist at the latest in seven or eight years'time, and the strategic nuclear forces will be transformed from a triad into a dyad. On the other hand, because of the failure to comply with the schedule for medium-level maintenance of existing submarine strategic missile complexes, none of them will be left in service by 2006-2007. As for the new Borey submarine strategic missile complexes, because of underfunding the naval strategic nuclear forces will be able to have one or at most two submarines in service by 2010 . Overall, under the optimistic scenario in 2010 the Russian strategic nuclear forces will have 550-600 nuclear warheads, and under the realistic scenario they will have 300-350 warheads.

("Address to members of the CPRF faction in the State Duma regarding the debate over ratification of the START II treaty," Nezavisimoye Voyennoye Obozreniye, 5-18 June, 1998, pp. 1,4 [FBIS-TAC-98-156]). 


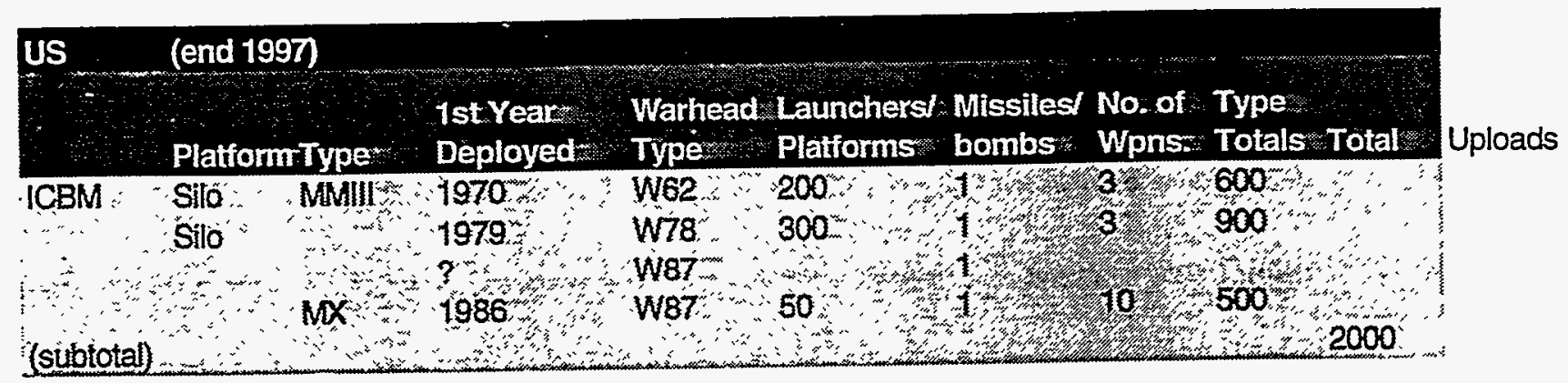

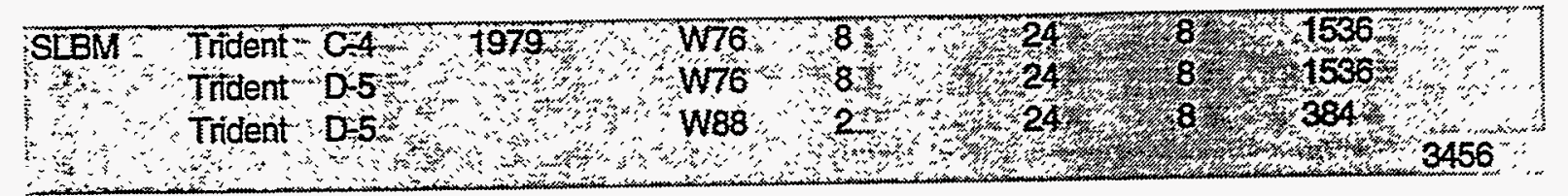

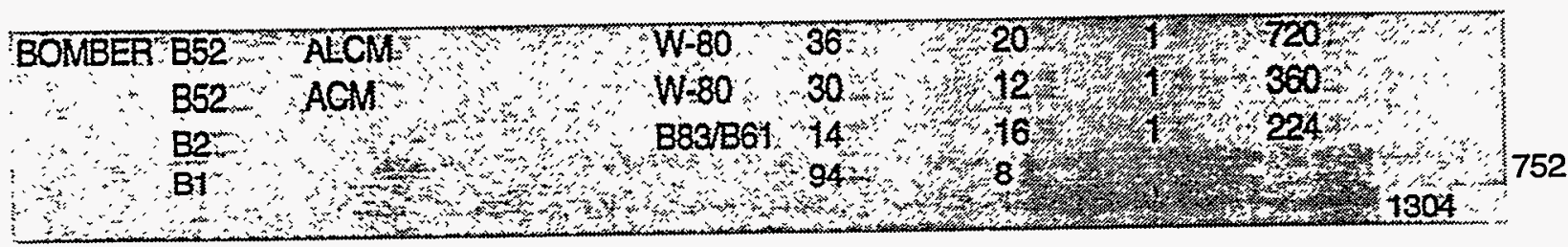

\section{RF- (end 1997)}

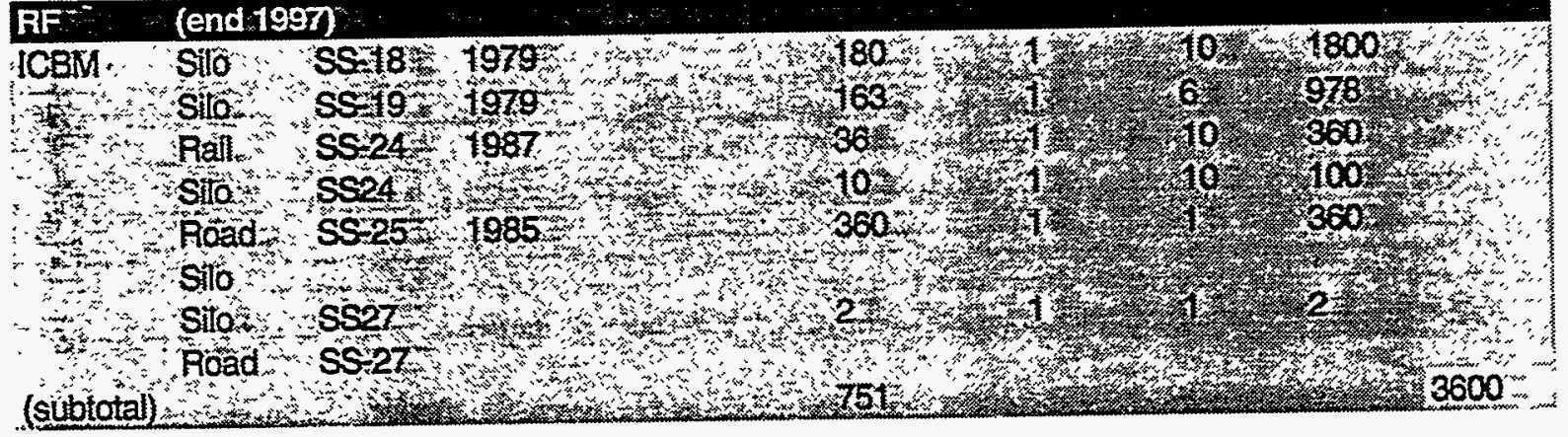

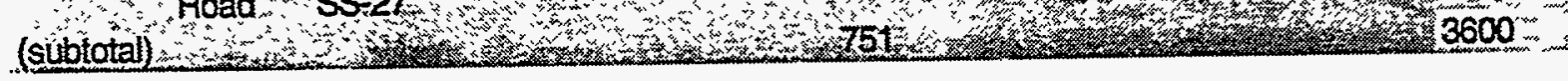
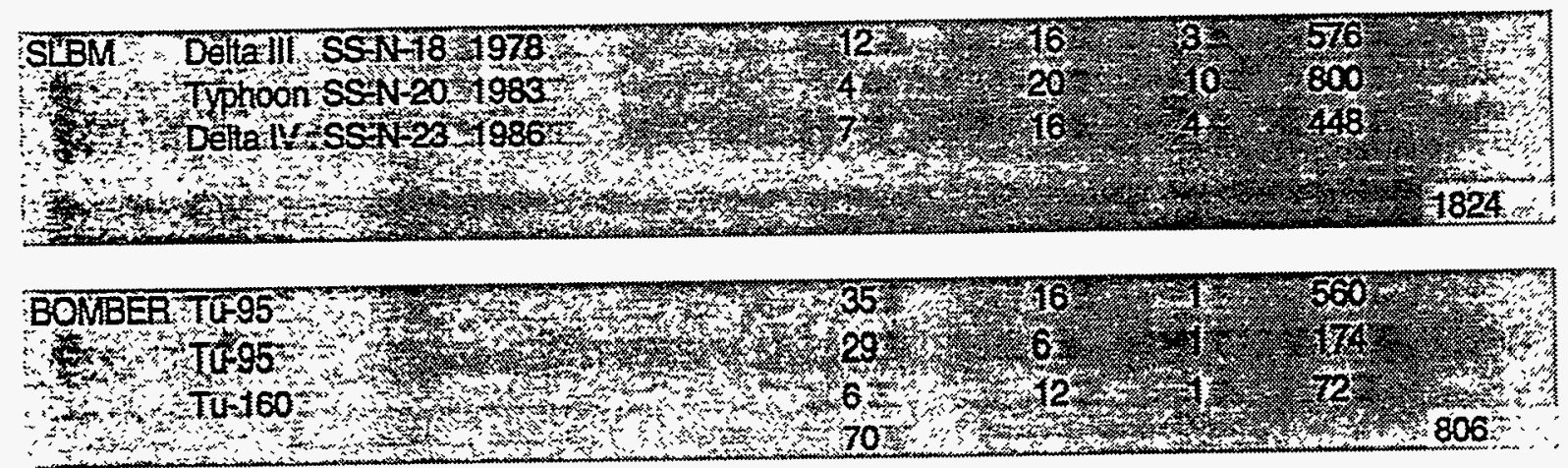


\section{Strategic Nuclear Forces START II}

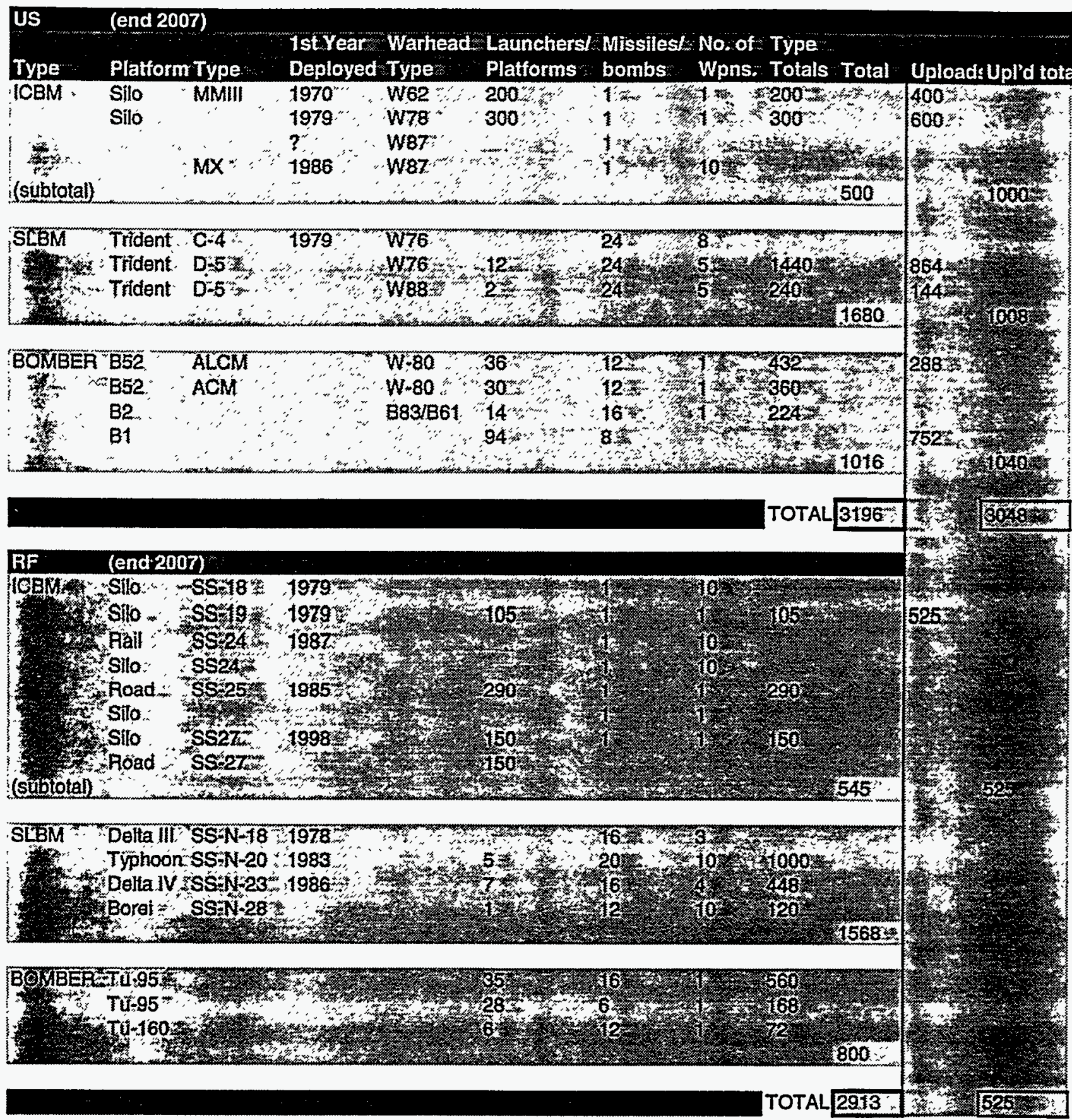




\section{Strategic Nuclear Forces $\quad$ START III -- 2000-250D}

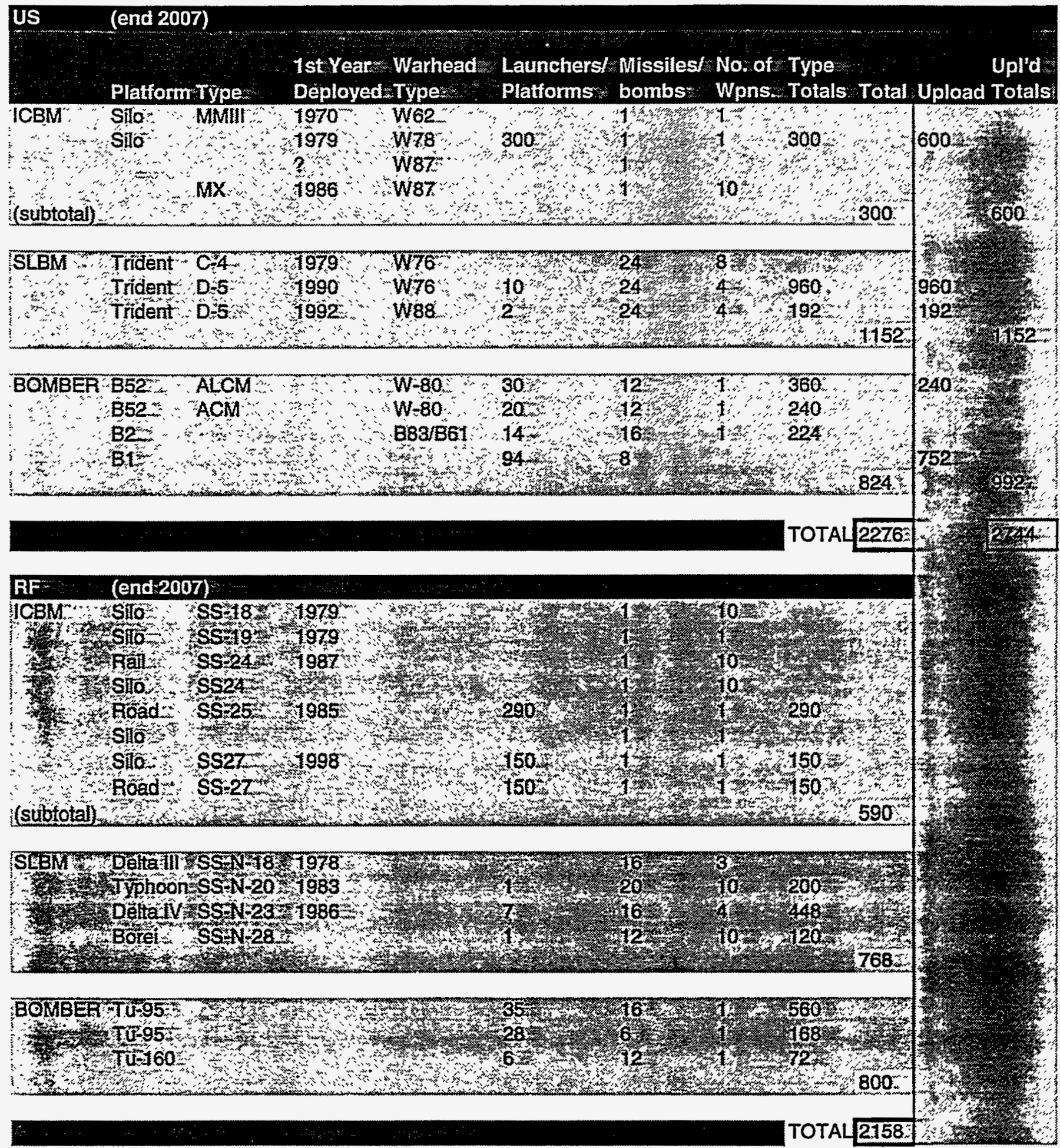




\section{Strategic Nuclear Forces START III -1500}

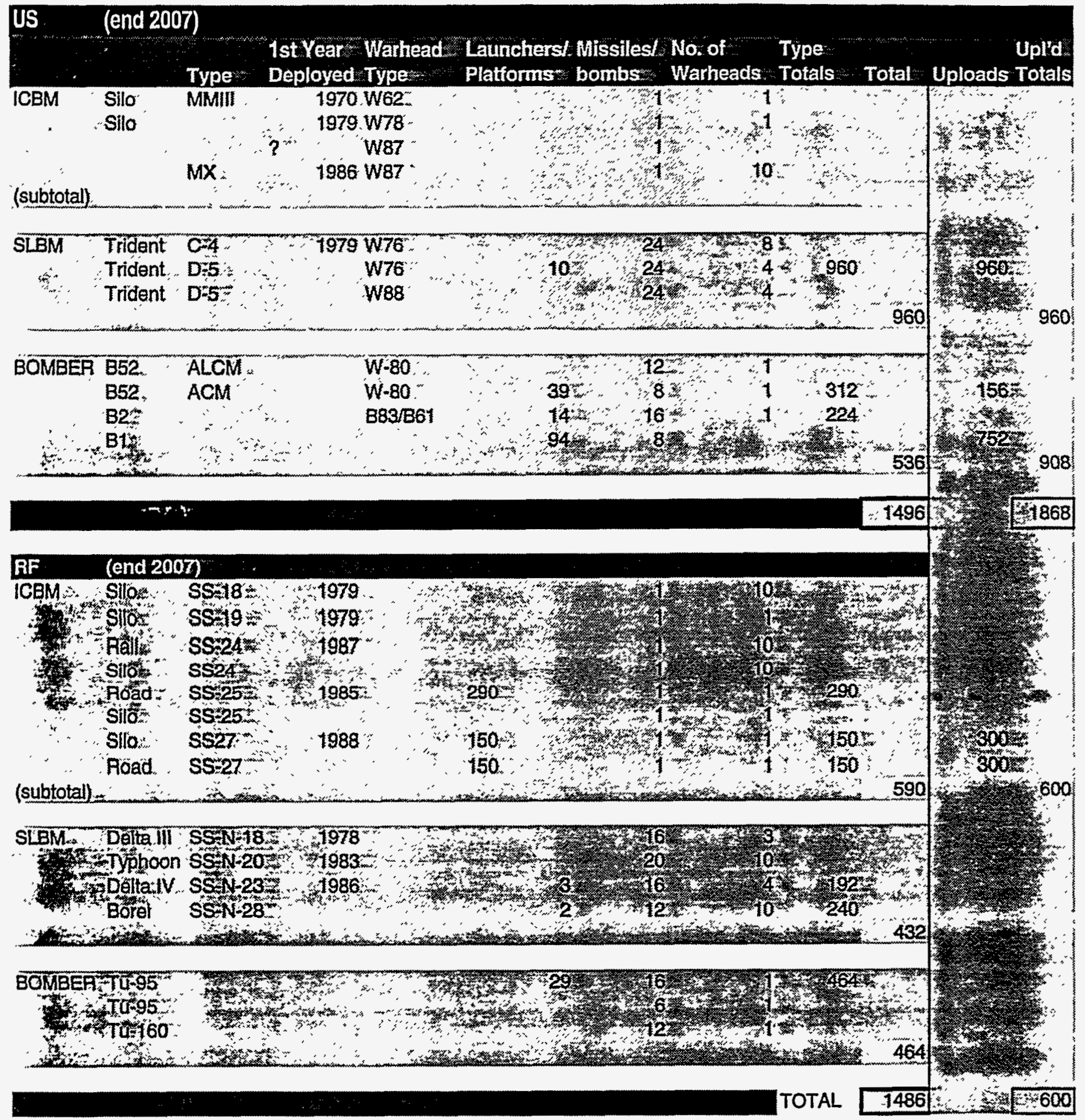




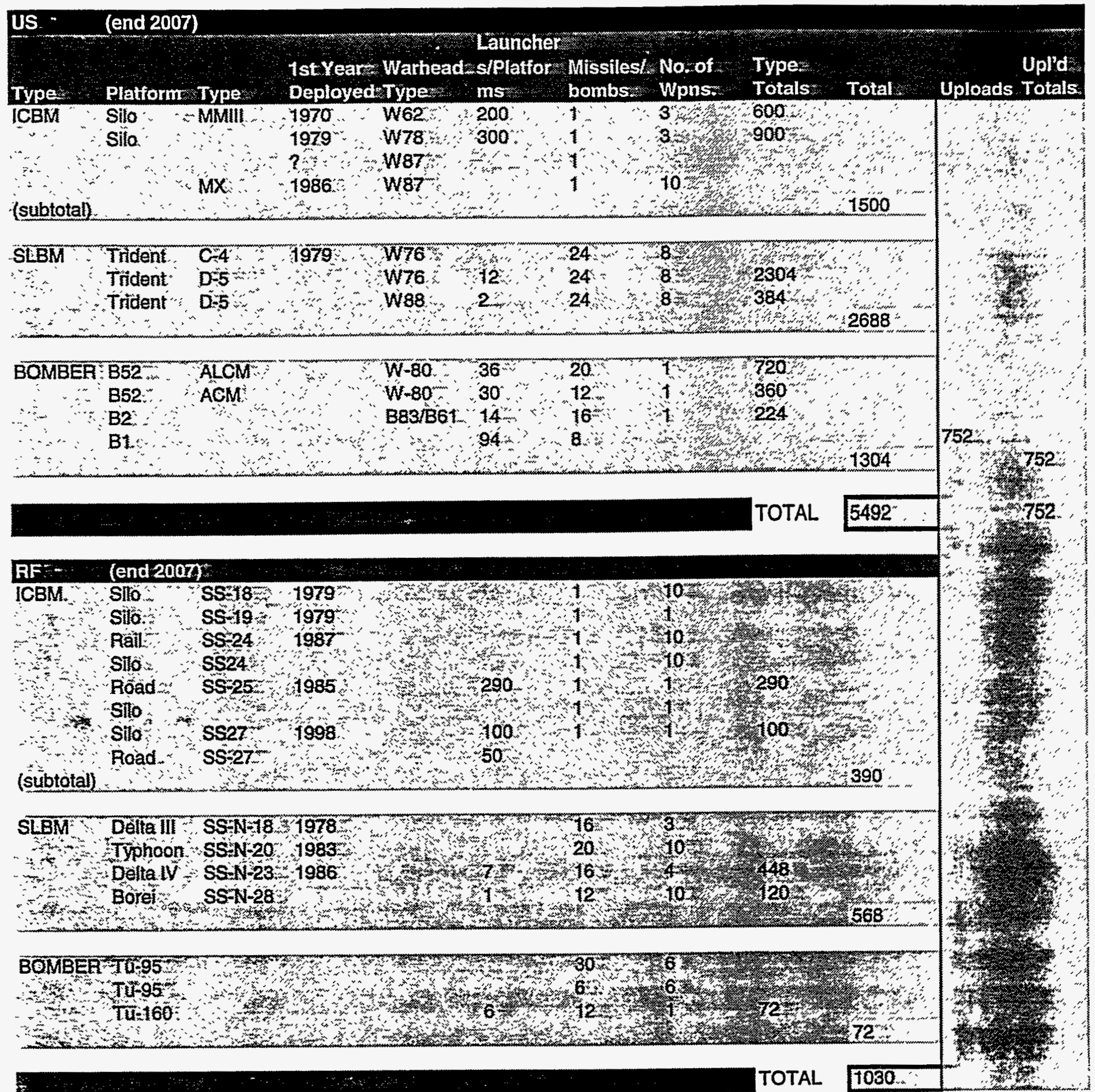


Distribution:

1 MS 9018 Central Technical Files, 8940-2

2 MS 0899 Technical Library, 4916

2 MS 0619 Review \& Approval Desk, 12690, for DOE/OSTI

30 MS 0425 Thomas Karas, 5415 